\title{
Neuregulin-1 Signals from the Periphery Regulate AMPA Receptor Sensitivity and Expression in GABAergic Interneurons in Developing Neocortex
}

\author{
Yuichi Abe, ${ }^{1 *}$ Hisaaki Namba, ${ }^{1 *}$ Taisuke Kato, ${ }^{1}$ Yuriko Iwakura, ${ }^{1}$ and Hiroyuki Nawa ${ }^{1,2}$ \\ ${ }^{1}$ Department of Molecular Neurobiology, Brain Research Institute and ${ }^{2}$ Center for Transdisciplinary Research, Niigata University, Niigata, 951-8585, Japan
}

\begin{abstract}
Neuregulin-1 (NRG1) signaling is thought to contribute to both neuronal development and schizophrenia neuropathology. Here, we describe the developmental effects of excessive peripheral NRG1 signals on synaptic activity and AMPA receptor expression of GABAergic interneurons in postnatal rodent neocortex. A core peptide common to all NRG1 variants (eNRG1) was subcutaneously administered to mouse pups. Injected eNRG1 penetrated the blood-brain barrier and activated ErbB4 NRG1 receptors in the neocortex, in which ErbB4 mRNA is predominantly expressed by parvalbumin-positive GABAergic interneurons. We prepared neocortical slices from juvenile mice that were receiving eNRG1 subchronically and recorded inhibitory synaptic activity from layer V pyramidal neurons. Postnatal eNRG1 treatment significantly enhanced polysynaptic IPSCs, although monosynaptic IPSCs were not affected. Examination of excitatory inputs to parvalbumin-containing GABAergic interneurons revealed that eNRG1 treatment significantly increased AMPA-triggered inward currents and the amplitudes and frequencies of miniature EPSCs (mEPSCs). Similar effects on mEPSCs were observed in mice treated with a soluble, full-length form of NRG1 type I. Consistent with the electrophysiologic data, expression of the AMPA receptor GluA1 (i.e., GluR1, GluRA) was upregulated in the postsynaptic density/cytoskeletal fraction prepared from eNRG1-treated mouse neocortices. Cortical GABAergic neurons cultured with eNRG1 exhibited a significant increase in surface GluA1 immunoreactivity at putative synaptic sites on their dendrites. These results indicate that NRG1 circulating in the periphery influences postnatal development of synaptic AMPA receptor expression in cortical GABAergic interneurons and may play a role in conditions characterized by GABA-associated neuropathologic processes.
\end{abstract}

\section{Introduction}

Neuregulin-1 (NRG1) is a neurotrophic factor that has been implicated in genetic vulnerability to schizophrenia (Stefansson et al., 2002). Although multiple isoforms of NRG1 precursor proteins (types I-VI) are generated by alternative splicing, all NRG1 isoforms contain an epidermal growth factor (EGF)-like core domain (eNRG1) (Burden and Yarden, 1997; Buonanno and Fischbach, 2001; Mei and Xiong, 2008). Soluble forms of NRG1 isoforms are produced from membrane-anchored precursors by metalloproteases: these variants are liberated in a neural activitydependent manner to bind ErbB3 or ErbB4 NRG1 receptors (Falls, 2003; Ozaki et al., 2004; Li et al., 2007). Stimulation of ErbB4 on neuronal cell surfaces or postsynaptic membranes alters the expression of NMDA and $\mathrm{GABA}_{\mathrm{A}}$ receptors (Ozaki et al.,

\footnotetext{
Received June 14, 2010; revised Dec. 17, 2010; accepted Feb. 16, 2011.

Author contributions: H.Nam. and H.Naw. designed research; Y.A., H.Nam., T.K., and Y.I. performed research; Y.A., H.Nam., and H.Naw. analyzed data; Y.A. and H.Naw. wrote the paper.

This study was supported by a Grant-in-Aid for Basic Scientific Research (B), a Grant-in-Aid for Young Investigator (B), Core Research for Evolutional Science and Technology from the Japan Science and Technology Corporation, and a grant for Promotion of Niigata University Research Projects.

*Y.A. and H.Nam. contributed equally to this work.

Correspondence should be addressed to Hiroyuki Nawa, Department of Molecular Neurobiology, Brain Research Institute, Niigata University, 1-757 Asahimachi, Chuo-ku, Niigata, 951-8585, Japan. E-mail: hnawa@bri.niigata-u.ac.jp.

DOI:10.1523/JNEUROSCI.3477-10.2011

Copyright $\odot 2011$ the authors $\quad 0270-6474 / 11 / 315699-11 \$ 15.00 / 0$
}

1997; Okada and Corfas, 2004; Xie et al., 2004) and affects clustering of $\alpha 7$ nicotinic acetylcholine receptors (Zhong et al., 2008). How the neurotrophic activity of NRG1 contributes to developmental and/or synaptic plasticity in individual neuronal populations has not been fully elucidated, however.

Studies of the roles of NRG1 in synaptic neurophysiology have revealed opposing activities under phasic and tonic conditions. Acute application of NRG1 decreases NMDA currents and attenuates long-term potentiation in cortical and hippocampal pyramidal neurons (Gu et al., 2005; Kwon et al., 2008). In neocortical and hippocampal GABAergic neurons, acute NRG1 treatment enhances inhibitory transmission and function (Woo et al., 2007; Fisahn et al., 2009). In a chronic paradigm, ErbB4 overexpression elevates basal AMPA currents but not NMDA currents in hippocampal pyramidal neurons (Li et al., 2007). Thus, NRG1 exerts a diverse set of neurotrophic functions that depend on the target cell population, developmental time window, and duration of exposure.

Neocortical GABAergic interneurons also express TrkB and ErbB1 receptors for brain-derived neurotrophic factor (BDNF) and EGF (Cellerino et al., 1996; Kornblum et al., 1997; Fox and Kornblum, 2005; Hashimoto et al., 2005). These neurotrophic factors positively or negatively regulate postnatal phenotypic differentiation and synaptic maturation in this neuronal population (Nawa and Takei, 2001; Nagano et al., 2003, 2007; Namba et al., 2006). Our findings suggest that these factors alter the sensitivity 
and expression of AMPA receptors in neocortical GABAergic neurons during postnatal development, although the specific synaptic effects depend on species of neurotrophic factor. Conversely, the effects of excessive NRG1 signals on AMPA receptors have not been fully characterized in this neuronal population $(\mathrm{Li}$ et al., 2007; Fazzari et al., 2010).

In the present investigation, we focused on immature GABAergic interneurons at the postnatal stage, at which point the developing neurons have completed tangential migration (Yau et al., 2003; Flames et al., 2004). We used electrophysiologic approaches to investigate the subchronic effects of NRG1 on synaptic inputs and outputs of this neuronal population. To explore the molecular underpinnings of the observed synaptic events, we also analyzed AMPA receptor expression in cortical tissues and cultures. The effects of peripheral NRG1 on GABAergic development and its contribution to schizophrenia neuropathology are discussed.

\section{Materials and Methods}

Neuregulin administration. Pregnant C57BL/6N mice (gestation day 18) were purchased from SLC. Mouse dams were housed in a temperaturecontrolled colony room $\left(22 \pm 1.0^{\circ} \mathrm{C}\right)$, maintained under a $12 \mathrm{~h} \mathrm{light} /$ dark cycle (7:00 A.M. lights on, 7:00 P.M. lights off) with access to food and water ad libitum, and allowed to give birth. We generated the full mature form of recombinant type I NRG1 $\beta 1$ protein (fNRG1) with the conventional recombinant technique, which carries the tag sequence of six histidine residues at its C-terminal end (Kato et al., 2011). Alternatively, we obtained the core EGF domain of NRG1 $\beta 1$ (eNRG) from PeproTech. eNRG1 is an artificial peptide product common to all NRG1 splice variants. We put the biotin tag on eNRG1 protein using the EZ-Link sulfoNHS-LC-biotinylation kit from Pierce. eNRG1 or biotinylated eNRG1 (1 $\mu \mathrm{g} / \mathrm{g}$ body weight) was subcutaneously administered to newborn mice on postnatal day 2 (P2). Alternatively, eNRG1 or fNRG1 was repeatedly administered to half of each newborn litter on P2-P10. Control littermates received saline injections. All animal experiments were authorized by the Animal Use and Care Committee of Niigata University and were performed in accordance with the National Institutes of Health Guidelines for Care and Use of Laboratory Animals. All efforts were made to minimize the number of animals used and their suffering.

In situ hybridization. In situ hybridization was performed as described previously (Abe et al., 2009). Mice at P18 were transcardially perfused with $4 \%$ paraformaldehyde in $0.1 \mathrm{~m}$ sodium phosphate buffer, $\mathrm{pH}$ 7.4. Fourteen-micrometer-thick coronal sections of the frontal cortex (1.0$0.0 \mathrm{~mm}$ anterior from bregma) were cut using a cryostat (CM1510; Leica). The sections were hybridized with digoxigenin (DIG)-labeled cRNA probes corresponding to nucleotides 429-1042 of the ErbB4 gene (NM_010154) in the National Center for Biotechnology Information database. To detect hybridization signals, sections were incubated in $1 \%$ blocking reagent with alkaline phosphatase (AP)-conjugated sheep antiDIG antibodies (Roche Diagnostics). AP activity was visualized using nitroblue tetrazolium chloride plus 5-bromo-4-chloro-3-indolyl phosphate toluidine salt solution (Roche Diagnostics).

For immunostaining of parvalbumin combined with in situ hybridization, cRNA-hybridized sections were incubated overnight with polyclonal anti-parvalbumin antibodies (1:2000; Abcam) at $4^{\circ} \mathrm{C}$. Sections were incubated with AP-conjugated sheep anti-DIG antibodies and Alexa Fluor 488-labeled anti-mouse IgG (1:200; Invitrogen). A 2-hydroxy3-naphtoic acid-2'-phenylanilide phosphate fluorescent detection kit was used to visualize anti-DIG immunoreactivity (Roche Diagnostics). Images were obtained with a digital camera (DP50-CU; Olympus) attached to a microscope (Axioskop50; Carl Zeiss). No specific binding was observed in control sections treated with sense probes (data not shown). Single- and double-labeled cells expressing ErbB4 and parvalbumin were counted in all layers of the frontal cortex. The positive cells were defined as those exhibiting more than twofold higher signals than the background fluorescence level. The results are expressed as average percent- ages of the total number of ErbB4- or parvalbumin-positive cells in 23 sections from four mice.

Electrophysiology. Juvenile mice (P11-P12, P21-P23) were anesthetized with halothane and decapitated. Brains were placed in cold highsucrose artificial CSF (ACSF) containing the following (in mM): 195 sucrose, $1 \mathrm{NaH}_{2} \mathrm{PO}_{4}, 2.5 \mathrm{KCl}, 5 \mathrm{MgSO}_{4}, 1.0 \mathrm{CaCl}_{2}, 26.2 \mathrm{NaHCO}_{3}$, and 11 D-glucose at $\mathrm{pH}$ 7.4. The solution was saturated with $95 \% \mathrm{O}_{2}$ and $5 \%$ $\mathrm{CO}_{2}$. Slices of frontal cortex (primary motor area; thickness, 300-350 $\mu \mathrm{m}$ ) were cut in an oblique plane (Kawaguchi and Kubota, 1997) with a microslicer (Pro7; Dosaka). Slices were placed in an incubation chamber for at least $1 \mathrm{~h}$ at room temperature $\left(24-26^{\circ} \mathrm{C}\right)$. The chamber was filled with ACSF containing the following (in $\mathrm{mm}$ ): $119 \mathrm{NaCl}, 1.0 \mathrm{NaH}_{2} \mathrm{PO}_{4}$, $2.5 \mathrm{KCl}, 1.3 \mathrm{MgSO}_{4}, 2.5 \mathrm{CaCl}_{2}, 26.2 \mathrm{NaHCO}_{3}$, and 11 D-glucose. Wholecell patch-clamp recordings were performed at room temperature. Slices were placed in a recording chamber that was continuously perfused with normal ACSF at $\sim 3.0 \mathrm{ml} / \mathrm{min}$. Individual cells in layer $\mathrm{V}$ of the frontal cortex were visualized with an upright infrared differential interference contrast video microscope. Slice patch-clamp recordings were obtained using an Axopatch 200B amplifier (Molecular Devices). Patch pipettes were prepared from borosilicate glass capillaries pulled to a tip resistance of 3-6 M $\Omega$. All data were filtered at $2 \mathrm{kHz}$ and digitized at a sampling rate of $10 \mathrm{kHz}$. Data were acquired using Clampex 7 (Molecular Devices). No whole-cell capacitance or series resistance compensation was made. Series resistance was determined by measuring the current response to a -5 $\mathrm{mV}$ pulse from the holding potential. Recorded data with a series resistance of $>30 \mathrm{M} \Omega$ or cases in which the series resistance changed by $>10 \%$ were excluded.

We measured evoked IPSCs and EPSCs in layer V pyramidal neurons in the presence of $25 \mu \mathrm{M}$ DL-2-amino-5-phosphonopentanoic acid (APV). Patch pipettes were filled with an internal solution containing the following (in mM): $117 \mathrm{CsMeSO}_{3}, 2.8 \mathrm{NaCl}, 20 \mathrm{HEPES}, 0.4$ EGTA, 5 tetraethylammonium-Cl, 2.5 Mg-ATP, and 5 QX314-Cl [2(triethylamino)- $\mathrm{N}$-(2,6-dimethylphenyl) acetamine chloride], $\mathrm{pH} 7.4$ (with sucrose to adjust the osmolarity to $290 \mathrm{mOsm})$. Constant electric stimuli $(0.1-0.7 \mathrm{~mA}, 50 \mu \mathrm{s})$ were given at $0.1 \mathrm{~Hz}$ using a microconcentric bipolar stimulating electrode placed in the white matter. To measure monosynaptic and paired-pulse IPSCs, the stimulating electrode was placed $100-200 \mu \mathrm{m}$ lateral to the recording position. Monosynaptic responses were evoked with electric stimuli $(0.06-0.5 \mathrm{~mA}, 50$ $\mu \mathrm{s})$ at $0.1 \mathrm{~Hz}$ and pharmacologically isolated in the presence of $10 \mu \mathrm{M}$ 6-cyano-7-nitroquinoxaline-2,3-dione (CNQX) and $25 \mu \mathrm{M}$ APV to block excitatory glutamatergic transmission. Paired-pulse IPSCs (interstimulus intervals, 25-200 ms) were triggered with electric stimuli $(0.1-0.2 \mathrm{~mA}, 50$ $\mu \mathrm{s})$ at $0.1 \mathrm{~Hz}$ in the presence of $10 \mu \mathrm{M}$ CNQX and $25 \mu \mathrm{M}$ APV. EPSCs were recorded by holding the membrane at the IPSC reversal potential $(-47.5$ $\mathrm{mV})$, whereas IPSCs were recorded at the EPSC reversal potential $(+4 \mathrm{mV})$.

To record AMPA-evoked currents and miniature EPSCs (mEPSCs), pipettes were filled with an internal solution containing the following (in mM): $122.5 \mathrm{KMeSO}_{3}, 7.5 \mathrm{KCl}, 10 \mathrm{HEPES}, 0.2$ EGTA, and $4 \mathrm{Mg}$-ATP, pH 7.4 (with sucrose to adjust the osmolarity to $290 \mathrm{mOsm}$ ). We compensated for the membrane and holding potentials using the liquid junction potential $(-9 \mathrm{mV})$. Parvalbumin-positive neurons were identified by nonadapting repetitive firing with fast spiking (Kawaguchi and Kubota, 1997; Itami et al., 2007). For AMPA application, a second pipette was prepared and filled with $100 \mu \mathrm{M}$ AMPA (Tocris Cookson). The sibling pipette exhibited the tip resistance of 4.5-5.0 $\mathrm{M} \Omega$ with the same recording solution. The AMPA-filled pipette was located $\sim 5 \mu \mathrm{m}$ away from the soma, and AMPA was locally applied using a picospritzer (6 psi, 5-40 ms; WPI). AMPA-evoked currents and mEPSCs were recorded at a holding potential of -79 and $-69 \mathrm{mV}$, respectively, in the presence of $1 \mu \mathrm{M}$ TTX (Wako), $50 \mu \mathrm{M} \mathrm{APV}$, and $10 \mu \mathrm{M}$ (-)-bicuculline methiodide (Sigma). Miniature events were detected with a $6 \mathrm{pA}$ threshold level of detection in the Mini Analysis Program (Jaejin Software).

Western blotting. Mice were anesthetized with ice or halothane, and tissues were dissected immediately after decapitation. Brains were immersed in ice-cold PBS. Frontal cortex was homogenized by sonication in $2 \%$ SDS buffer containing phosphatase inhibitors $\left(2 \mathrm{mM} \mathrm{NaVO}_{4}\right.$ and 10 $\mathrm{mm} \mathrm{NaF}$ ) and a protease inhibitor cocktail (Complete Mini; Roche). Alternatively, subcellular fractionation was performed using a previously described method (McNeill and Colbran, 1995; Narisawa-Saito et al., 
1999). Tissue was homogenized using a Teflon homogenizer in ice-cold homogenization buffer containing the following (in mM): 10 Tris- $\mathrm{HCl}$, pH 7.5, 2 EDTA, 1 DTT, $2 \mathrm{NaVO}_{4}, 1$ phenylmethylsulfonyl fluoride, and $10 \mathrm{NaF}$. Homogenates were separated by centrifugation $(100,000 \times g$ for $60 \mathrm{~min}$ ) into supernatant (cytosolic proteins) and a pellet containing the crude membranes. The pellet was rehomogenized in 1\% Triton X-100containing buffer using a sonicator and subjected to centrifugation $(100,000 \times g$ for $60 \mathrm{~min})$ to give rise to supernatant (M2; membrane fraction) and precipitate [P2; postsynaptic density (PSD)/cytoskeletal fraction]. The precipitate was rehomogenized in $2 \%$ SDS-containing buffer. After centrifugation, we added $5 \times$ sample buffer $(0.31 \mathrm{M}$ Tris $\mathrm{HCl}$, pH 6.8, 10\% SDS, 50 mm glycerol, 25\% 2-mercaptoethanol, and $0.001 \%$ bromophenol blue) to the M2 and P2 fractions and boiled the sample at $95^{\circ} \mathrm{C}$ for $5 \mathrm{~min}$.

Protein extract $(10,20$, or $100 \mu \mathrm{g} /$ lane $)$ was subjected to $7.5 \%$ SDSPAGE and transferred to a nitrocellulose membrane (Schleicher and Schull). The membrane was probed with primary antibodies, washed, and incubated with species-specific secondary antibodies conjugated to horseradish peroxidase (Jackson ImmunoResearch), followed by a chemiluminescence reaction (ECL kit; PerkinElmer Life and Analytical Sciences). Densitometric quantification of band intensity was performed with NIH ImageJ.

Anti-PSD-95 antibodies were purchased from Affinity BioReagents. Anti-NR2A antibodies were obtained from Millipore. Anti-ErbB4 (1: 2000; sc-283) antibodies were obtained from Santa Cruz Biotechnology. Anti-phospho-ErbB4 (Tyr1284) (1:2000, 21A9), anti-phospho-ErbB3, and anti-ErbB3 antibodies were purchased from Cell Signaling Technology. Antibodies specific for GluA1 (synonyms: GluRA and GluR1), GluA2/3 (synonyms: GluRB and GluR2/3), NR1, NR2B, synaptophysin, and $\beta$-actin were purchased from Millipore Bioscience Research Reagents.

Culture preparations. Neocortex from embryonic day 19 (E19) rats (Sprague Dawley; Nihon SLC) was dissected and treated with papain (Nagano et al., 2003). Dissociated neurons were suspended and plated in poly-D-lysine-coated dishes at a density of 200-300 cells $/ \mathrm{mm}^{2}$ in DMEM containing $10 \%$ fetal bovine serum. One day after plating, neurons were grown in DMEM containing $0.5 \mathrm{~mm}$ glutamine and nutrient mixture N2 (Nagano et al., 2003). eNRG1 $(25 \mathrm{ng} / \mathrm{ml})$ was added to the culture medium daily from day in vitro (DIV) 7 to DIV13.

Immunohistochemistry. After whole-cell recordings, biocytin-filled cells were visualized, and parvalbumin immunoreactivity was examined according to the procedure described by Kawaguchi and Kubota (1997). Briefly, brain sections were fixed in $4 \%$ paraformaldehyde and sequentially incubated with 15 and $30 \%$ sucrose solution. After freezing and thawing, sections were treated with $0.1 \% \mathrm{NaBH}_{4}$ to reduce background fluorescence and incubated with the anti-parvalbumin antibodies (1: 3000; Abcam) in buffer containing 5\% BSA and 0.5\% Triton X-100 for 2 d. Slices were then incubated with Alexa Fluor 488-conjugated antirabbit Ig antibodies (1:200; Invitrogen) and streptavidin Alexa Flour 594 (1:200; Invitrogen).

To stain surface GluA1 receptors in culture, live neurons at DIV14DIV15 were treated for $15 \mathrm{~min}$ at $37^{\circ} \mathrm{C}$ with antibodies specific for the extracellular region of GluA1 (1:15; Calbiochem) (Nagano et al., 2007). Cultures were then washed in cold PBS and fixed in $4 \%$ paraformaldehyde and $2 \%$ sucrose for $15 \mathrm{~min}$. After incubation with anti-rabbit IgG secondary antibodies conjugated to Alex Fluor 488 (1:200; Invitrogen), cultures were fixed again for $10 \mathrm{~min}$ in $4 \%$ paraformaldehyde and $2 \%$ sucrose. Fixed cells were incubated with anti-glutamic acid decarboxylase 67 (GAD67) antibodies (1:2000; Millipore Bioscience Research Reagents) in $2 \%$ BSA plus $1 \%$ Triton X-100 for $1 \mathrm{~h}$, followed by anti-mouse IgG secondary antibodies conjugated to Alex Fluor 546 (1:500; Invitrogen). Fluorescence images were obtained using a BZ-9000 digital fluorescence microscope with a $100 \times$ objective lens (Keyence). Each area was only photographed once using a constant exposure time ( $0.66 \mathrm{~s})$ to minimize and normalize photobleaching. We identified GABAergic neurons based on GAD67 immunoreactivity and randomly selected dendritic regions spanning $20-40 \mu \mathrm{m}$ from the somata of positive cells. We measured the fluorescence intensity, frequency, and size of the individual GluA1-immunoreactive puncta in the selected regions using dynamic cell count BZ-H1C software (Keyence). The luminance range for the 8-bit digital images was set to $60-256$ for all pictures to isolate punctate GluA1 labeling located at putative postsynaptic structures.

Enzyme immunoassay. We subcutaneously administered biotinylated eNRG1 ( $1 \mu \mathrm{g} / \mathrm{g}$ body weight) to newborn mice (P2). One or $3 \mathrm{~h}$ after injection, ice-cold saline was transcardially perfused to wash out biotinylated eNRG1 in bloodstream. Frontal cortex was dissected out and homogenized in $10 \mathrm{vol}$ of homogenization buffer (PBS) containing protease inhibitors (aprotinin, 200 kallikrein units/ml), $0.1 \mathrm{~mm}$ phenylmethylsulfonyl fluoride, $0.1 \mathrm{~mm}$ benzethonium chloride, $1 \mathrm{~mm}$ benzamidine (all from Sigma), and $1 \mathrm{~mm}$ EDTA. Brain homogenates were centrifuged at $14,000 \times g$ for $30 \mathrm{~min}$ at $4^{\circ} \mathrm{C}$, and supernatants containing free eNRG1 were stored at $-80^{\circ} \mathrm{C}$ until use. Protein concentrations in the samples were determined using a Micro BCA kit (Pierce) with bovine serum albumin as a standard.

Biotinylated eNRG1 levels in brain homogenates were measured by enzyme immunoassay (EIA) as described previously (Iwakura et al., 2005). EIA titer plates were coated with tissue extracts ( $100 \mu \mathrm{l}$ of 3.0 $\mu \mathrm{g} / \mathrm{ml}$ protein) or biotinylated eNRG1 standards $(0.1-10 \mathrm{ng} / \mathrm{ml})$ in $0.1 \mathrm{M}$ Tris buffer, pH 9.0. Biotinylated eNRG1 in wells was detected using streptavidin $\beta$-galactosidase (1:3000; Sigma). The enzyme activity retained in each well was measured by incubation with $200 \mu \mathrm{M}$ 4-methylumbelliferyl-D-galactosidase (Sigma). The fluorescent product was quantitated using an MTP-601F microplate reader (Corona) with excitation and emission at 365 and $450 \mathrm{~nm}$, respectively.

Statistical analysis. Results are presented as means \pm SEM. Electrophysiologic data were subjected to Mann-Whitney $U$ test nonparametric analysis or two-way repeated measures ANOVA, followed by a post hoc Fisher's least significant difference (LSD) test. To obtain cumulative probability distributions, mEPSCs were ranked by amplitude and the interevent interval. Univariate values for immunoreactivity on blots and cultures were subjected to Student's $t$ test or Wilcoxon's test. $p$ values $<$ 0.05 were considered statistically significant. Statistical analysis was performed using SPSS software (version 11.5; SPSS Japan).

\section{Results}

\section{Peripheral eNRG1 administration activates ErbB4 receptors in the neocortex of mouse neonates}

We tested the blood-brain barrier (BBB) permeability of the EGF core domain peptide of NRG1 (eNRG1; molecular weight, 7500 $\mathrm{Da})$ in mouse pups. We subcutaneously administered recombinant eNRG1 (1 $\mu \mathrm{g} / \mathrm{g}$ body weight) to newborn pups. To estimate the penetration of this peptide through the $\mathrm{BBB}$, we examined the activation of NRG1 receptors, ErbB3 and ErbB4. ErbB3 is expressed predominantly in oligodendrocytes, whereas ErbB4 is expressed in neurons in rodent cerebral neocortex (Steiner et al., 1999; Gerecke et al., 2001; Yau et al., 2003; Woo et al., 2007). Peripheral eNRG1 administration increased immunoreactivity for phosphorylated ErbB4 in the frontal cortex, and the increase was detected for $24 \mathrm{~h}$ without changes in ErbB4 levels (Fig. $1 \mathrm{~A}$ ). In contrast to ErbB4, the basal expression of ErbB3 was markedly lower at this developmental stage, and eNRG1 injection modestly increased phosphorylation levels of ErbB3 (Fig. 1B). The marginal effect on ErbB3 phosphorylation indicated the limited influence of eNRG1 on glial populations at this developmental stage.

When eNRG1 was injected to postnatal mice at various postnatal time points, significant increases in ErbB4 phosphorylation were observed from P2 to P8 (Fig. 1C). ErbB4 phosphorylation, however, gradually decreased and was undetectable at P11. Using biotinylated eNRG1 protein, we confirmed its penetration across the neonatal BBB. Enzyme immunoassay revealed the timedependent permeation of eNRG1 into frontal cortex: the concentration of free biotinylated eNRG1 in this brain region was the highest $1 \mathrm{~h}$ after injection $(0.0 \pm 0.2 \mathrm{ng}$ at $0 \mathrm{~h}, 4.9 \pm 0.3 \mathrm{ng}$ at $1 \mathrm{~h}$, and $1.3 \pm 0.2 \mathrm{ng}$ at $3 \mathrm{~h}$, all per milligram tissue protein). These observations suggest that peripherally administered NRG1 effi- 
A

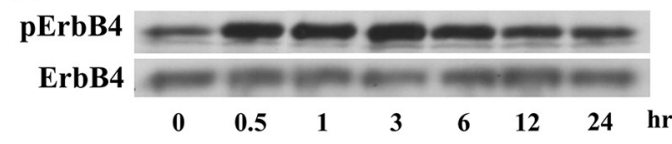

B
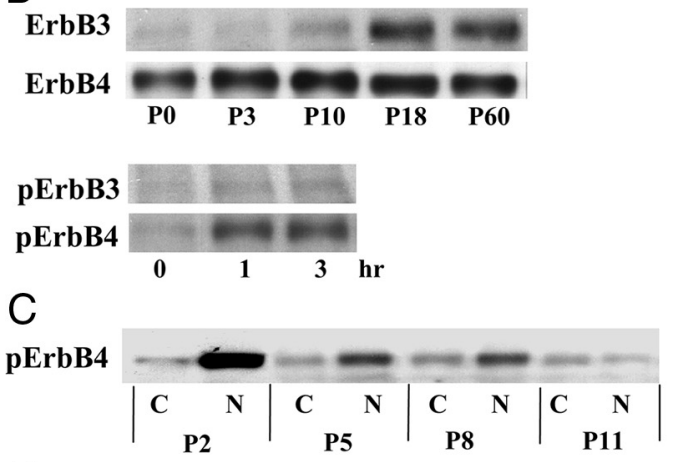

D

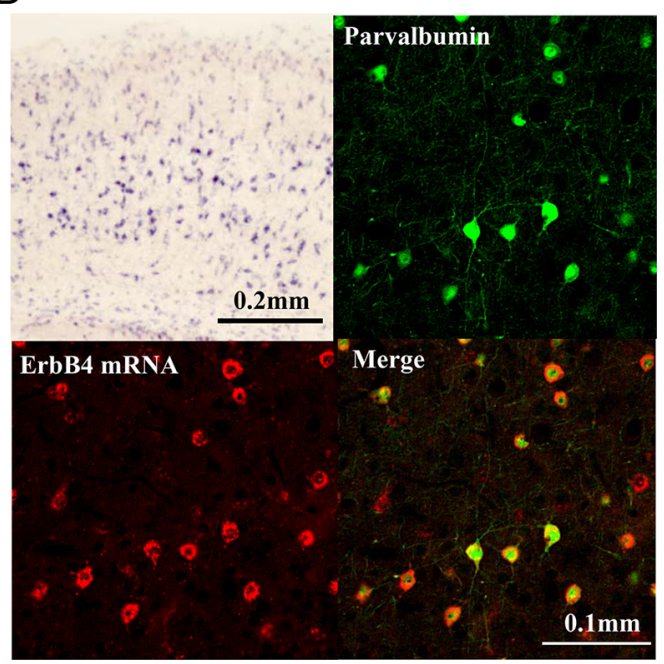

Figure 1. Subcutaneous eNRG1 injection activates ErbB4 receptors in the frontal cortex of postnatal mice. $A$, The time course of ErbB4 phosphorylation was examined after eNRG1 injections in neonatal mice (P2). Cortical tissues were removed at 0.5, 1, 3, 6, 12, and $24 \mathrm{~h}$ after injection and subjected to immunoblotting with anti-phospho-ErbB4 or anti-ErbB4 antibodies. B, Protein levels of ErbB3 and ErbB4 in the frontal cortex were examined at P0, P3, P10, P18, and P60. Phosphorylation levels of ErbB3 and ErbB4 were compared at 0,1 , and $3 \mathrm{~h}$ after injection. Note that ErbB3 levels in early postnatal days were very limited. C, Postnatal BBB penetration by eNRG1 was also estimated by monitoring ErbB4 phosphorylation at P2, P5, P8, and P11. C, Control; N, eNRG1. D, The distribution of ErbB4 mRNA was examined in the frontal cortices of juvenile mice using in situ hybridization and immunohistochemistry. Most ErbB4 mRNA colocalized with parvalbumin in frontal cortical layer $V$ at $P 18$, as revealed by double staining for parvalbumin (green) and ErbB4 mRNA (red). Note that the frequency of parvalbumincontaining neurons was calculated from a total of 10,608 cells expressing ErbB4 mRNA and that of ErbB4 mRNA-containing neurons was from a total of 5939 parvalbumin-positive cells expressing ErbB4 mRNA in the whole cortex (both 23 sections from four mice).

ciently permeates into the frontal cortex of mouse pups (Kleshcheva, 1988; Tohmi et al., 2007).

In adult rats, ErbB4 mRNA is highly expressed in cortical and hippocampal GABAergic interneurons (Yau et al., 2003; Woo et al., 2007; Vullhorst et al., 2009). To examine the postnatal cellular localization of ErbB4 in mice, we performed in situ hybridization analysis of ErbB4 mRNA. Most ErbB4 mRNA was localized in the parvalbumin-containing cells of layer $\mathrm{V}$ frontal cortex (Fig. $1 D$ ). Some ErbB4 mRNA-positive neurons in the superficial cortex lacked parvalbumin immunoreactivity, however. Throughout the cortical layers at this stage, $98.8 \pm 0.3 \%$ of parvalbumin-
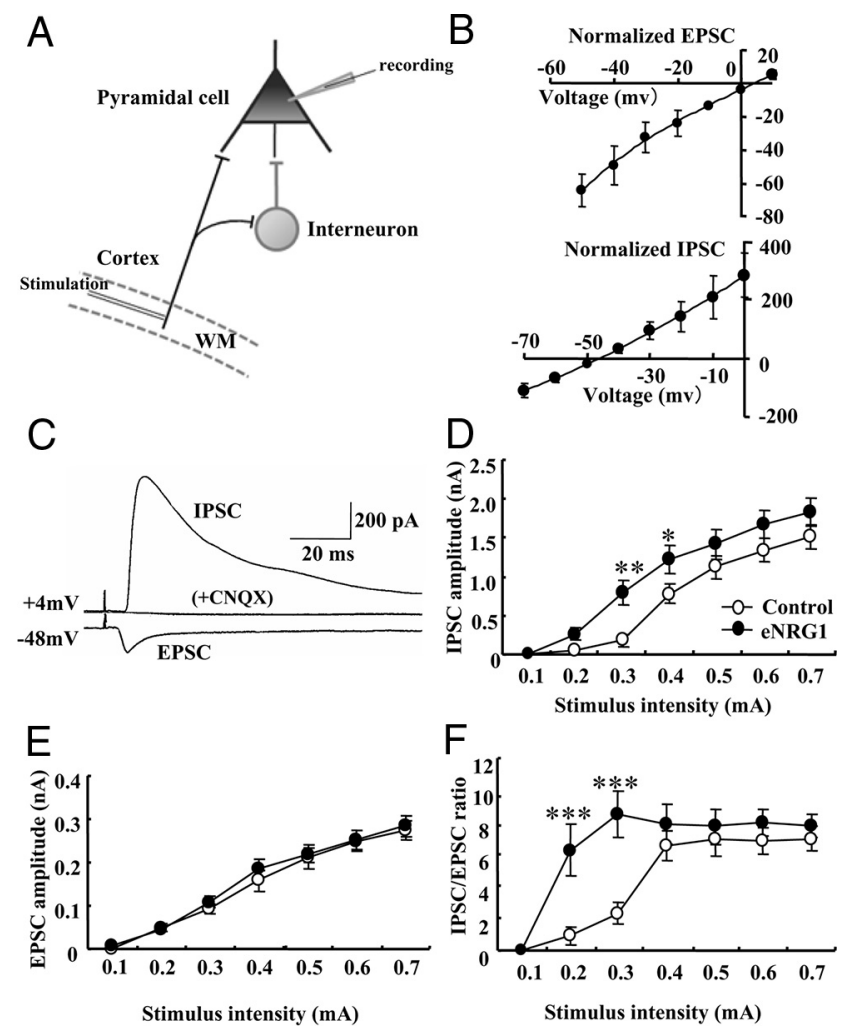

Figure 2. Polysynaptic IPSCS recorded in cortical pyramidal neurons of postnatal mice treated with eNRG1.A, A schematic of the experimental circuit used for patch-clamp recordings shown in $\boldsymbol{C}-\boldsymbol{F}$. Slices of frontal cortex were prepared from the P11-P12 postnatal mice that had been treated with eNRG1 or saline for $9 \mathrm{~d}$. Recordings were made from layer V pyramidal neurons, and electrical stimuli were delivered to the white matter (WM). $\boldsymbol{B}$, Estimation of reversal potentials in evoked EPSCS and IPSCs. Normalized I-V curves for EPSCS and IPSCs in layer V pyramidal neurons were plotted. Synaptic currents were evoked by layer VI stimulation. EPSCS were isolated using $10 \mu \mathrm{m}$ bicuculline and $25 \mu \mathrm{m}$ APV. IPSCs were isolated using $10 \mu \mathrm{m}$ CNQX and $25 \mu \mathrm{m}$ APV in the bath. The mean reversal potentials for EPSCs and IPSCs were estimated to be +4 and $-47.5 \mathrm{mV}$, respectively ( $n=4$ for each). $C$, Typical traces for IPSCs and EPSCS are displayed. EPSCs were isolated at a holding potential of $-47.5 \mathrm{mV}$. IPSCs were isolated at a holding potential of $+4 \mathrm{mV}$. Of note, IPSCs with delayed onset latencies appeared to be evoked polysynaptically, because all of these IPSC components were blocked by CNQX. D, $\boldsymbol{E}$, Polysynaptic IPSCS $(\boldsymbol{D})$ and EPSCS $(\boldsymbol{E})$ were recorded from pyramidal neurons in the presence of $25 \mu \mathrm{m}$ APV. $\boldsymbol{F}$, The IPSC/EPSC ratio was calculated for each neuron and plotted (control, $n=$ 14 cells; NRG1, $n=17$ cells). ${ }^{*} p<0.05,{ }^{* *} p<0.01,{ }^{* * *} p<0.001$ compared with control mice at each stimulus intensity by Fisher's LSD.

containing neurons were positive for ErbB4 mRNA, and $55.3 \pm$ $0.7 \%$ of ErbB 4 mRNA-expressing neurons were parvalbumin positive ( $n=23$ sections from four mice).

\section{Increased IPSCs in neocortical pyramidal neurons from eNRG1-treated mice}

The localization of ErbB4 mRNA in cortical GABAergic neurons raised the possibility that eNRG1 administration can affect synaptic plasticity and/or development in this neuronal population. We subcutaneously injected eNRG1 from P2 to P10 and prepared cortical slices from P11-P12 mice. We recorded inhibitory synaptic currents in layer $\mathrm{V}$ pyramidal neurons after stimulating the white matter in the presence of APV (Fig. $2 \mathrm{~A}$ ). Pyramidal neurons were voltage clamped at the IPSC or EPSC reversal potential, which were estimated in independent experiments (Fig. $2 B$ ). Traces of synaptic currents revealed that the IPSC latency was greater than the EPSC latency, and both were abolished by CNQX (Fig. 2C). These observations suggest that the IPSCs represented 

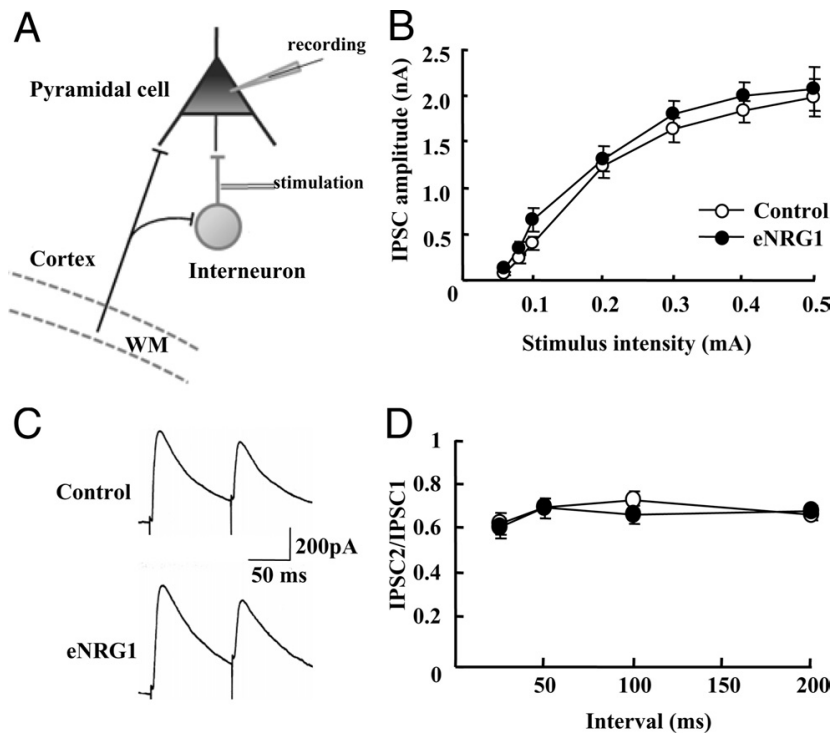

Figure 3. Monosynaptic IPSCs recorded in pyramidal neurons from mice treated with eNRG1. A, A schematic of the experimental circuit. Recordings were made from layer V pyramidal neurons responding to local stimuli delivered $100-200 \mu \mathrm{m}$ away from the recording electrode. $\boldsymbol{B}$, IPSCs were recorded at a holding potential of $+4 \mathrm{mV}$ in the presence of $10 \mu \mathrm{M}$ CNQX and $25 \mu \mathrm{m}$ APV (control, $n=23$ cells; eNRG1, $n=26$ cells). Of note, we assumed that the CNQX-resistant IPSCS were monosynaptic. C, Typical traces show IPSCs elicited by a paired pulse in control and eNRG1-treated mice. $\boldsymbol{D}$, The paired-pulse ratios (peak amplitude of EPSC2/peak amplitude of EPSC1) at each stimulus interval $(25,50,100$, and $200 \mathrm{~ms}$ ) were calculated (control, $n=11$ cells; eNRG1, $n=17$ cells).

polysynaptic responses of GABAergic neurons (Ling and Benardo, 1995; Sasaki et al., 2006).

Graded electrical stimulation (0.1-0.7 mA) was used to assess the relative activation levels of polysynaptic IPSCs and EPSCs. IPSC data were subjected to two-way repeated-measures ANOVA, which detected a significant interaction between stimulus intensity and eNRG1 treatment $\left(F_{(6,174)}=2.33 ; p<0.05\right)($ Fig. $2 D)$. Subsequent post hoc analysis revealed that eNRG1 treatment increased the amplitudes of IPSCs at lower stimulus intensities of 0.3 and $0.4 \mathrm{~mA}$. There were no significant differences in IPSCs triggered by high-intensity stimuli, however. In contrast, eNRG1 treatment had no effect on EPSCs in pyramidal neurons (Fig. $2 E)$. To normalize the variation in stimulation efficacy among slices, IPSC/EPSC ratios were also calculated for each cell, and their averages were plotted against the relative stimulus intensity (Fig. $2 F$ ). ANOVA again revealed an interaction between stimulus intensity and eNRG1 treatment $\left(F_{(6,174)}=5.41 ; p<0.01\right)$, and post hoc analysis showed that the IPSC/EPSC ratios at 0.2 and $0.3 \mathrm{mV}$ were larger in the eNRG1-treated group than in the control group.

To determine whether the increase in polysynaptically evoked IPSCs was simply a result of enhanced efficacy of GABAergic outputs, we assessed the effects of eNRG1 on monosynaptic IPSCs and mIPSCs. The electrode was placed 100-200 $\mu \mathrm{m}$ away from the somata of patched pyramidal neurons, and GABAergic afferent fibers were stimulated at various intensities (Fig. $3 A$ ). IPSCs were recorded in the presence of CNQX $(10 \mu \mathrm{M})$ and APV $(25 \mu \mathrm{M})$ to isolate inhibitory monosynaptic events. Two-way repeated-measures ANOVA revealed that there was no significant difference in IPSC amplitudes in eNRG1-treated and vehicle-treated mice $\left(F_{(1,47)}=1.309 ; p=0.258\right)$ (Fig. 3B), suggesting that eNRG1 does not markedly affect monosynaptic IPSCs. In addition, we monitored spontaneous mIPSCs from layer V pyramidal cells in cortical slice preparations and assessed the effects of eNRG1 on the mIPSC amplitude and frequency (supplemental Fig. S1, available at www.jneurosci.org as supplemental material). Mann-Whitney $U$ tests detected no significant differences in the amplitude and frequency of mIPSCs recorded from control and eNRG1-treated groups. Both results suggest that the direct effects of eNRG1 on their inhibitory outputs were limited.

We also measured IPSCs in a paired-pulse paradigm to estimate the effects of eNRG1 on the release probability of GABA (Fig. 3C,D). For example, if the probability of GABA release is higher, a second stimulation generates a smaller IPSC because the first stimulation have triggered higher amounts of GABA release and reduced the number of GABA vesicles in the releasable pool (Lambert and Wilson, 1994; Fleidervish and Gutnick, 1995; Woo et al., 2007). Under our recording conditions, paired-pulse stimulation with various interpulse intervals $(20-200 \mathrm{~ms})$ elicited a similar degree of synaptic depletion (Fig. 3D). eNRG1 administration did not affect the paired-pulse ratios at any of the interpulse intervals $\left(F_{(1,26)}=0.138 ; p=0.713\right)$. These results indicate that postnatal eNRG1 treatment did not influence the presynaptic property of GABAergic terminals.

\section{Subchronic NRG1 treatment alters mEPSCs in parvalbumin-positive interneurons}

The parvalbumin-positive cells belong to one of the major subpopulations of cortical GABAergic interneurons (Kawaguchi and Kubota, 1997; Kawaguchi and Kondo, 2002; Dumitriu et al., 2007). We examined the effects of eNRG1 treatment on excitatory synaptic inputs of this cell population. We identified putative parvalbumin-positive GABA neurons by monitoring their firing properties - nonadapting repetitive firing of fast spikes at $>70 \mathrm{~Hz}$ - after depolarizing current injections (Fig. 4A) (Kawaguchi and Kubota, 1997; Itami et al., 2007; Puig et al., 2008). The frequency of depolarization-triggered spiking was not significantly altered by subchronic eNRG1 treatment (Table 1). We analyzed spontaneous miniature events in these neurons to determine whether changes in the evoked IPSCs resulted from an increase in excitatory neurotransmission in the input synapses (Fig. 4B). eNRG1 administration increased the mean mEPSC amplitude in the fast-spiking cells (control, $18.2 \pm 0.5 \mathrm{pA}$; eNRG1, $21.7 \pm 0.6 \mathrm{pA}, p<0.01$, Mann-Whitney $U$ test) (Fig. $4 C, D)$. In contrast, there was no significant difference in mEPSC frequency (control, $4.9 \pm 0.7 \mathrm{~Hz}$; eNRG1, 6.2 $\pm 0.9 \mathrm{~Hz}$ ). A significant change was also detected in the kinetics of the averaged mEPSCs (control, $0.70 \pm 0.03 \mathrm{~ms}$; eNRG1, $0.60 \pm 0.02 \mathrm{~ms}, p=$ 0.013 for rise time; control, $2.56 \pm 0.11 \mathrm{~ms}$; eNRG1, $2.27 \pm 0.42$ $\mathrm{ms}, p=0.06$ for decay time, both Mann-Whitney $U$ test). However, series resistance and other electrophysiologic properties were not markedly affected (Table 1 ). In contrast to the fastspiking cells, eNRG1 had no effect on mEPSCs in pyramidal neurons from layer $\mathrm{V}$ of the frontal cortex (control, $11.2 \pm 0.3 \mathrm{pA}$; eNRG, $11.8 \pm 0.3$ pA for amplitude, $p=0.133$; control, $1.95 \pm$ $0.17 \mathrm{~Hz}$; eNRG1, $1.92 \pm 0.11 \mathrm{~Hz}$ for frequency, $p=0.818$, both Mann-Whitney $U$ test).

In addition, we tested fNRG1 (molecular weight, 25,400 Da) in the same experimental paradigm (Fig. 5). The mean of mEPSC amplitudes (control, $19.4 \pm 0.5 \mathrm{pA}$; NRG, $22.2 \pm 0.6 \mathrm{pA}, p<$ 0.01 , Mann-Whitney $U$ test) and frequencies (control, $5.7 \pm 0.8$ $\mathrm{Hz}$; NRG1, $9.3 \pm 1.2 \mathrm{~Hz}, p<0.05$, Mann-Whitney $U$ test) were significantly increased in the fast-spiking cells of full-length NRG1 type I-treated mice. In contrast to the effect of eNRG1, 


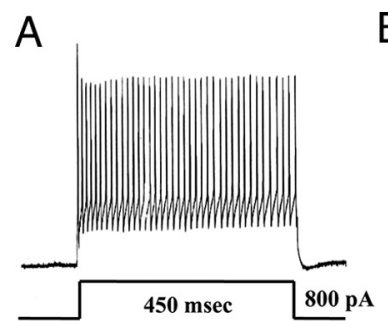

C
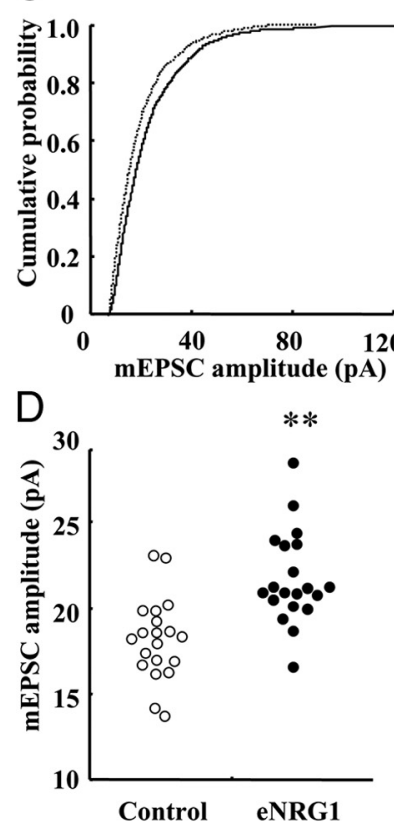

B Control
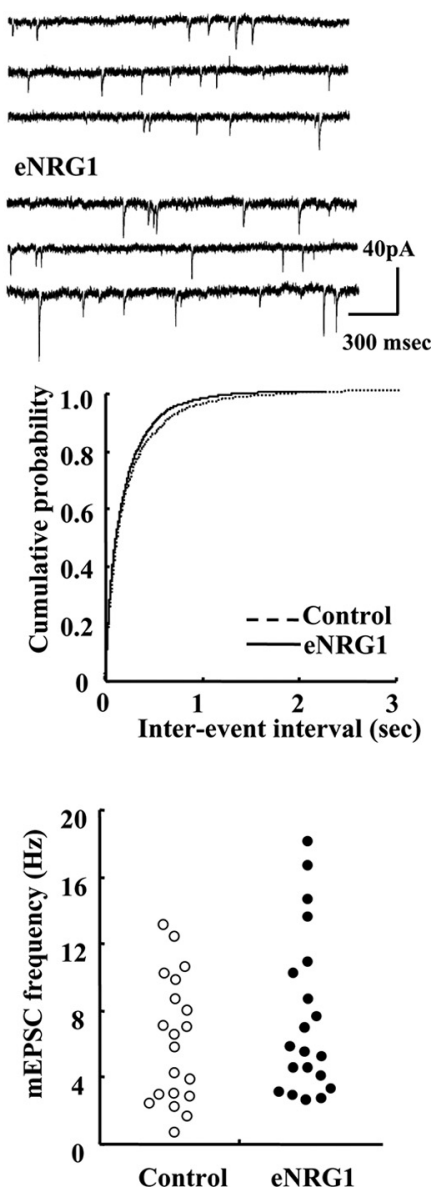

Figure 4. Amplitudes and frequencies of $\mathrm{mEPSC}(\mathrm{in}$ fast-spiking neurons in postnatal mouse neocortex. $A$, Putative parvalbumin-positive interneurons were identified based on characteristic firing properties, i.e., nonadapting repetitive firing of fast spikes at $>70 \mathrm{~Hz}$ with an $800 \mathrm{pA}$ current injection. $\boldsymbol{B}$, Typical traces of $\mathrm{mEPSCs}$ from eNRG1-treated and vehicle-treated (control) mice. C, Cumulative distributions of mEPSC amplitudes and interevent intervals were calculated from spontaneous synaptic events recorded from fast-spiking neurons from layer V. $\boldsymbol{D}$, Mean amplitudes (left) and frequencies (right) of mEPSCs in the same cells (control, $n=20$ cells; eNRG1, $n=20$ cells). ${ }^{* *} p<0.01$, Mann-Whitney $U$ test.

Table 1. Electrophysiologic properties of fast-spiking neurons

\begin{tabular}{lcc}
\hline & Control $(n=20)$ & eNRG1 $(n=20)$ \\
\hline Series resistance $(\mathrm{M} \Omega)$ & $16.0 \pm 0.8$ & $15.6 \pm 0.8$ \\
Input resistance $(\mathrm{M} \Omega)$ & $258 \pm 23$ & $274 \pm 20$ \\
Capacitance $(\mathrm{pF})$ & $115 \pm 7$ & $113 \pm 4$ \\
AHP amplitude $(\mathrm{mV})$ & $-22.4 \pm 0.9$ & $-20.5 \pm 0.6$ \\
Voltage sag $(\mathrm{mV})$ & $-8.7 \pm 1.8$ & $-8.8 \pm 1.1$ \\
Resting potential $(\mathrm{mV})$ & $-59.1 \pm 1.0$ & $-56.5 \pm 1.3$ \\
AP frequency $(\mathrm{Hz})$ & $78.1 \pm 2.4$ & $78.7 \pm 2.4$
\end{tabular}

Input resistance and series resistance were determined by measuring the current response to a $-5 \mathrm{mV}$ pulse from the holding potential. Cell capacitance measurements were made by integrating capacitive transients. Afterhyperpolarization (AHP) was determined after the first action potential (AP) triggered by the minimum depolarizing current $(100-300 \mathrm{pA})$. Voltage sag was determined by measuring voltage responses to a hyperpolarizing current $(-400 \mathrm{pA}, 450 \mathrm{~ms})$. Action potentials were generated by current injection $(800 \mathrm{pA}, 450 \mathrm{~ms})$, and their frequency was measured. No statistical differences were detected in these electrophysiologic properties.

fNRG1 effects were apparent in both frequency and amplitude of mEPSCs at this stage.

To examine the developmental continuity of the eNRG1 effects, we prepared cortical slices at the age of P21-P23. Because the expression of parvalbumin becomes detectable at this stage (Kawaguchi and Kubota, 1997; Itami et al., 2007; Puig et al.,
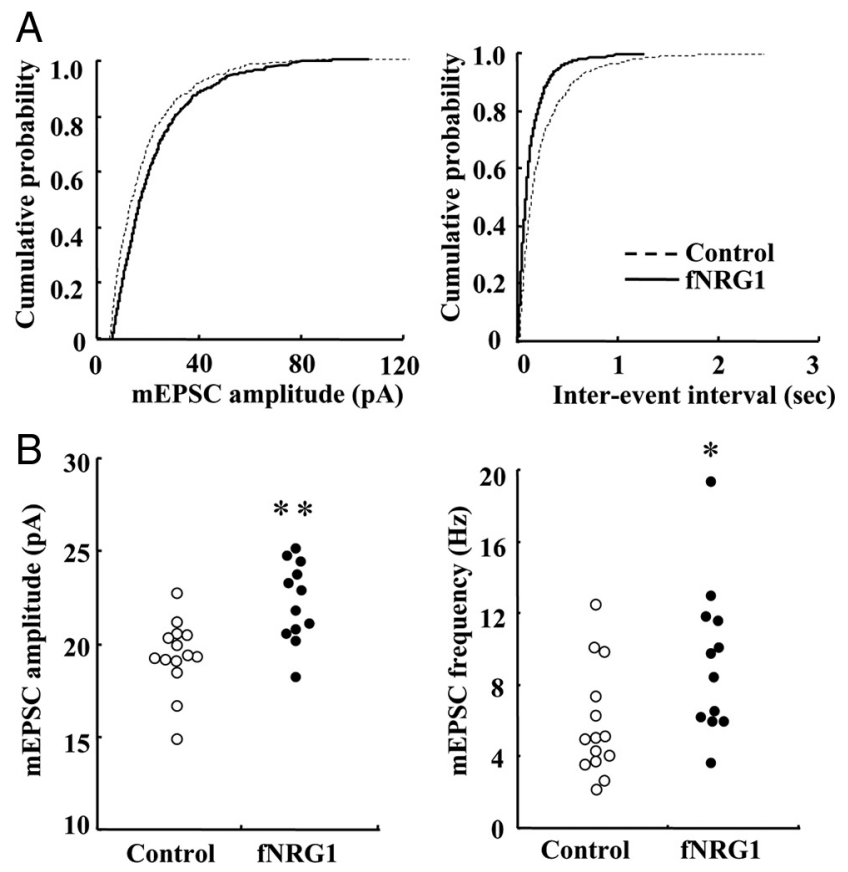

Figure 5. Subchronic effects of fNRG1 on excitatory transmission in fast-spiking neurons Slices of frontal cortex were prepared from the P11-P12 postnatal mice that had been treated with fNRG1 for $9 \mathrm{~d}$. $\boldsymbol{A}$, Cumulative distributions of mEPSC amplitudes and interevent intervals were calculated from spontaneous synaptic events recorded from fast-spiking neurons from layer V. $\boldsymbol{B}$, Mean mEPSC amplitudes (left) and frequencies (right) in the same cells (control, $n=$ 14 cells; eNRG1, $n=12$ cells). ${ }^{*} p<0.05$, ${ }^{* *} p<0.01$, Mann-Whitney $U$ test.

2008), we injected biocytin to fast-spiking cells to visualize these cells. Almost all the biocytin-labeled cells ( $94 \pm 4 \%, n=10$ mice) were positive for parvalbumin, confirming the authenticity of our target cell population (Fig. 6A). All biocytin-filled, parvalbuminpositive cells displayed typical multipolar cell morphology (Kawaguchi and Kubota, 1997; Kawaguchi and Kondo, 2002; Dumitriu et al., 2007). Even 10-12 d after the completion of eNRG1 treatment, there was a significant effect of eNRG1 on mEPSC frequency (control, $10.5 \pm 1.2 \mathrm{~Hz}$; eNRG1, $16.2 \pm 1.8$ $\mathrm{Hz}, p=0.021$, Mann-Whitney $U$ test) (Fig. 6B, C). However, there was no significant difference in mEPSC amplitudes at this stage (control, $17.0 \pm 0.4 \mathrm{pA}$; eNRG1, $17.8 \pm 0.7 \mathrm{pA}$ ). No significant changes were observed in the kinetics of the averaged mEPSCs as well as in membrane properties (data not shown). These results suggest that the impact of neonatal eNRG1 treatment on mEPSC frequency emerges with a time delay.

To examine whether the increases in evoked EPSCs and mEPSCs represent an increase in AMPA receptor function in the GABAergic cells, we recorded inward currents triggered by local application of the receptor agonist AMPA. Puff application of AMPA produced the typical inward currents representing the activity of the AMPA receptor channel complexes (Milstein and Nicoll, 2008), transient inward currents followed by slow currents (Fig. 7A). eNRG1 treatment significantly increased the amplitude of peak AMPA currents in the fast-spiking cells (Fig. 7B).

To estimate the difference between the acute and subchronic effects of eNRG1 in this cell subpopulation, we acutely treated cortical slices with eNRG1 and examined mEPSCs from fastspiking neurons. eNRG1 did not significantly affect the amplitude or frequency of the mEPSCs (supplemental Fig. S2, available at www.jneurosci.org as supplemental material). These results support our hypothesis that NRG1 regulation of excitatory synaptic inputs to these neurons requires tonic NRG1 signaling. 

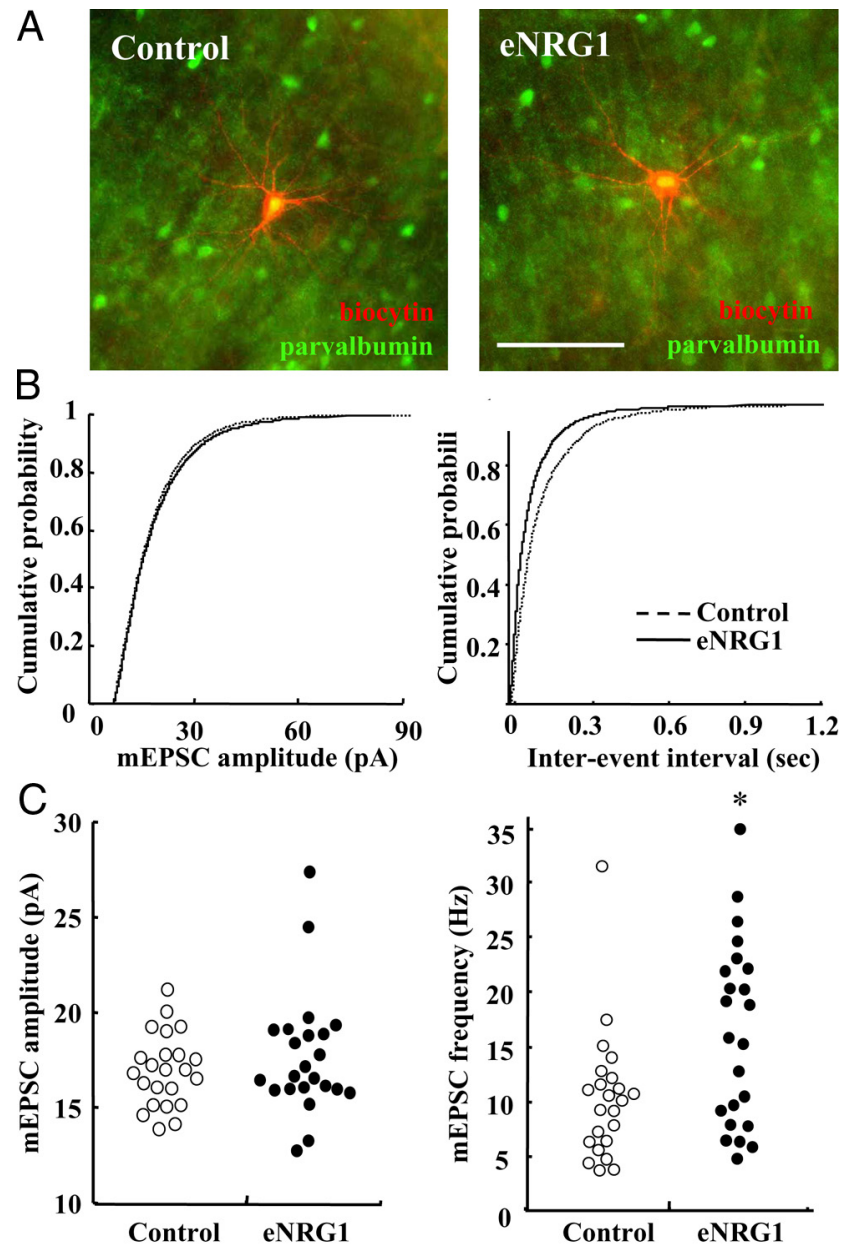

Figure 6. Delayed influences of postnatal eNRG1 treatment on frequencies of mEPSCs in fast-spiking neurons. Newborn mice were treated with eNRG1 for $9 \mathrm{~d}$ as described in Figure 2, but brain slices were prepared at P21-P23. A, Cells were labeled with biocytin and immunostained with anti-parvalbumin antibody (green) and Alexa Flour 594-conjugated streptavidin (red) after they were recorded. Of note, the strong fluorescent signals from the soma produced a flare artifact, which enlarges the soma appearance in these images. In comparison, parvalbumin immunoreactivity in the soma (yellow) is not so strong and looks relatively smaller. Scale bar, $50 \mu \mathrm{m}$. B, Cumulative distributions of mEPSC amplitudes and interevent intervals were calculated from spontaneous synaptic events recorded from fast-spiking neurons from layer $V$. C, Mean mEPSC amplitudes (left) and frequencies (right) in the same cells (control, $n=23$ cells; eNRG1, $n=23$ cells). ${ }^{*} p<0.05$, Mann-Whitney $U$ test.

eNRG1 elevates protein levels and synaptic accumulation of AMPA-type glutamate receptors

To test whether the enhanced synaptic AMPA currents involved increased glutamatergic receptor expression, we investigated the expression and subcellular localization of glutamate receptor subunits in the frontal cortex. We fractionated tissue samples into membrane (M2), PSD/cytoskeletal (P2), and cytoplasmic fractions (McNeill and Colbran, 1995; Narisawa-Saito et al., 1999). As expected, the PSD protein PSD95 and the membrane protein synaptophysin were highly enriched in the P2 and M2 fractions, respectively (Fig. $8 \mathrm{~A}$ ). In the $\mathrm{P} 2$ fraction from eNRG1treated postnatal mice, we observed a significant increase in levels of the AMPA receptor GluA1 (Fig. $8 B, C$ ). GluA2/3 protein levels were not altered, however. The NMDA receptor subunit NR2A was expressed at lower levels in eNRG1-treated animals $(p=$ 0.003). NR1 and NR2B levels were not changed. Reduced ErbB4 levels in the P2 fraction-likely as a result of receptor internalization-were also observed, but there were no significant changes

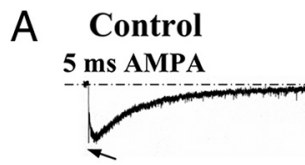

eNRG1

5 ms AMPA
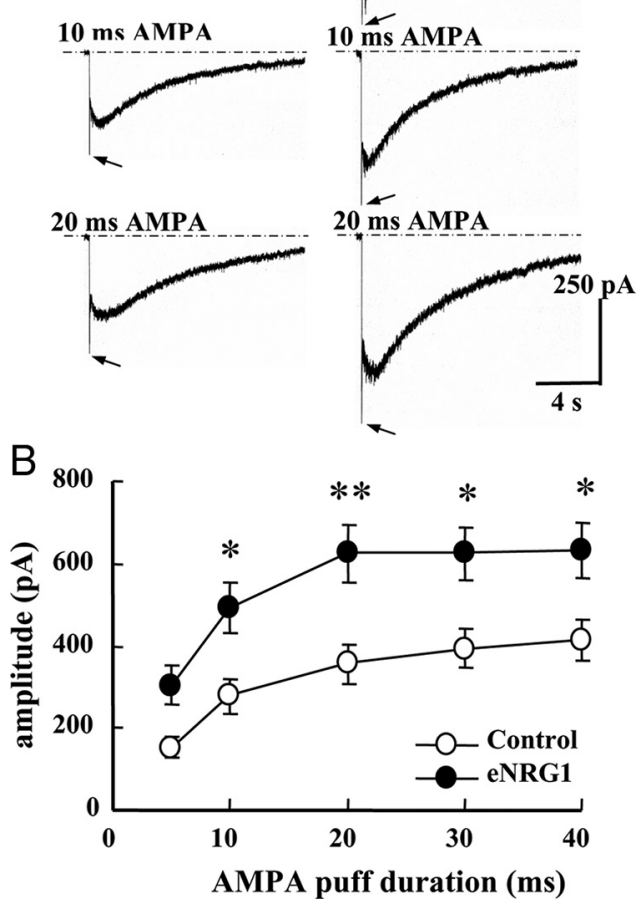

Figure 7. AMPA-evoked inward currents in fast-spiking neurons in eNRG1-treated and vehicle-treated mice. Slices of frontal cortex were prepared from the P11-P12 postnatal mice that had been treated with eNRG1 or saline. A, AMPA (100 $\mu \mathrm{M})$ was locally applied to the soma using air pressure for various durations $(5,10,20$, and $40 \mathrm{~ms})$. The figure displays typical AMPAevoked currents when cells were clamped at $-79 \mathrm{mV}$. $\boldsymbol{B}$, The amplitude of peak currents was measured from fast-spiking neurons (control, $n=20$ cells; NRG1, $n=20$ cells). Two-way repeated-measures ANOVA revealed a significant main effect $\left(F_{(1,38)}=9.59 ; p=0.004\right)$ without an interaction between AMPA puff duration and eNRG1 treatment $\left(F_{(4,152)}=1.836 ; p=\right.$ 0.125). ${ }^{*} p<0.05,{ }^{* *} p<0.01$, Fisher's LSD.

in other scaffold proteins, SAP97, PSD95, GRIP1, and Pick1 (supplemental Fig. S3, available at www.jneurosci.org as supplemental material). In the M2 and total protein fractions, however, there were no significant changes in AMPA and NMDA receptor levels (supplemental Fig. S4, available at www.jneurosci.org as supplemental material). Although it is possible that eNRG1 treatment also enhanced the channel gating activity of AMPA receptors by inducing receptor phosphorylation (Swayze et al., 2004), no significant changes in $\mathrm{Ser}^{845}$ phosphorylation of GluA1 were observed in eNRG1-treated animals (supplemental Fig. S5, available at www.jneurosci.org as supplemental material).

To test whether the increased GluA1 levels in the P2 fraction reflected a specific eNRG1-induced response in GABAergic neurons, we analyzed synaptic GluAl expression by immunocytochemistry. We observed marked cellular colocalization of GluA1 and parvalbumin in cortical sections prepared from fixed juvenile mice (supplemental Fig S6 A, available at www.jneurosci.org as supplemental material). This observation agrees with previous reports that cortical GABAergic neurons are relatively enriched with the AMPA receptor subunit GluA1 (Kharazia et al., 1996; Narisawa-Saito et al., 1999; Kondo et al., 2000; Kim et al., 2006; Nagano et al., 2007). The resolution of our confocal microscopy system, however, failed to enable us to isolate individual GluA1positive synapses in parvalbumin- or GAD67-positive cells (data not shown). As an alternative, we treated neocortical cultures 
A

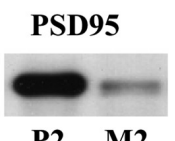

B

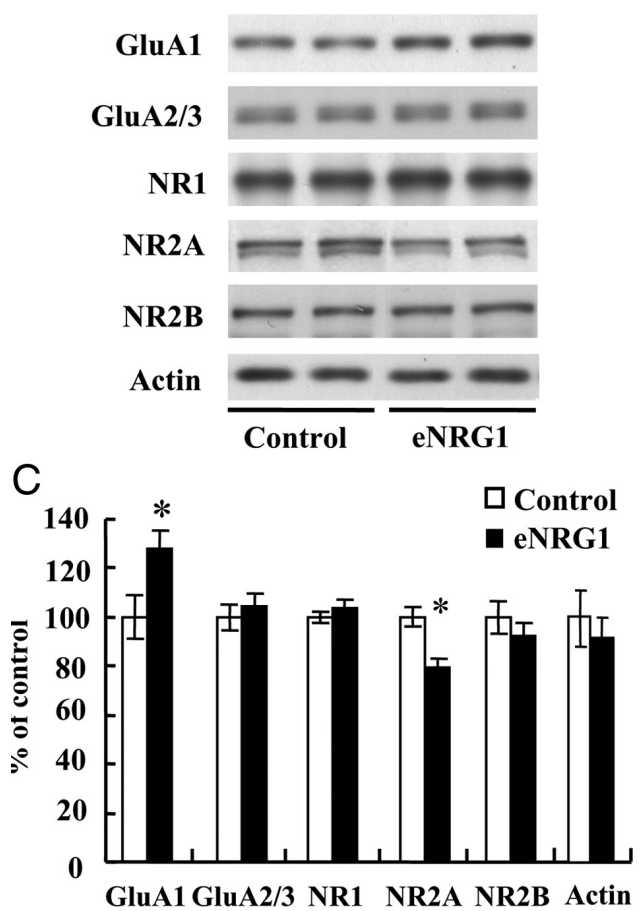

Figure 8. Changes in glutamate receptor levels in the PSD/cytoskeletal fraction. Frontal cortex was dissected from postnatal mice (P11) that had been treated with eNRG1 or vehicle (control) for $9 \mathrm{~d}$. Tissue homogenates were lysed with $1 \%$ Triton X-100, fractionated by centrifugation, and separated into the membrane fraction (M2) and PSD/cytoskeletal fraction (P2). $\boldsymbol{A}$, The fractionation efficiency was examined by Western blotting for PSD95 (a postsynaptic protein) and synaptophysin (a membrane protein). Each lane contained $10 \mu \mathrm{g}$ of total protein. $\boldsymbol{B}$, Immunoblots of the PSD/cytoskeletal fraction (P2) were probed with antibodies raised against AMPA receptor subunits (GluA1 and GluA2/3) and NMDA receptor subunits (NR1, NR2A, and NR2B). Representative immunoblots are shown. $\boldsymbol{C}$, Immunoreactivity levels were measured using densitometry ( $n=5$ mice each). Results were all normalized to the protein levels in control samples (100\%) and plotted. ${ }^{*} p<0.05, t$ test.

prepared from rat embryos with eNRG1 from DIV7 to DIV13. We immunolabeled live neurons with antibodies specific for the extracellular region of GluA1. Many GAD67-positive neurons displayed punctate GluA1 immunoreactivity along their dendrites, which presumably represented postsynaptic accumulation of the receptors (Fig. 9A,B). In contrast, most GAD67-negative neurons showed lower GluA1 labeling at these structures (supplemental Fig. S6B, available at www.jneurosci.org as supplemental material). Subchronic eNRG1 treatment triggered a significant increase in the mean intensity of GluAl immunoreactivity in the punctate structures (Fig. 9 C), whereas the mean density of GluA1 puncta along the dendrites was not affected (0.56 \pm $0.04 / \mu \mathrm{m}$ for control; $0.59 \pm 0.03 / \mu \mathrm{m}$ for eNRG, $p=0.56$ ). In particular, the difference in GluAl intensity was apparent in the higher ranges of GluA1 immunoreactivity. These results suggest that eNRG1 increases the accumulation of GluA1 at excitatory synapses on the dendrites of cortical GABAergic neurons.

\section{Discussion}

In the present study, we peripherally and subchronically administered recombinant eNRG1 or fNRG1 to mouse pups and exam-
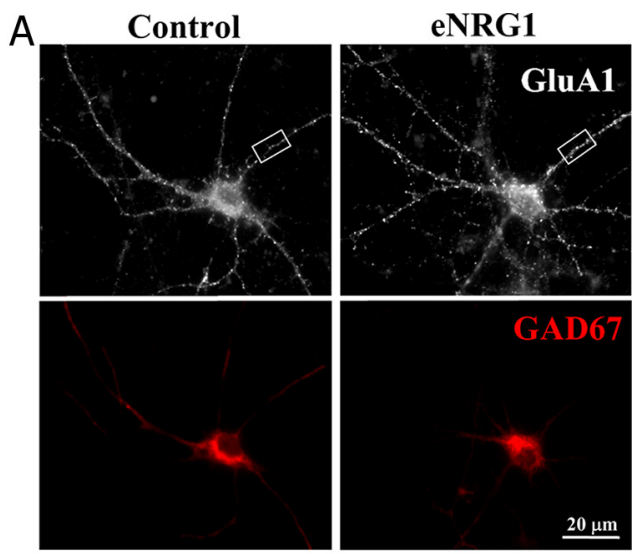

B

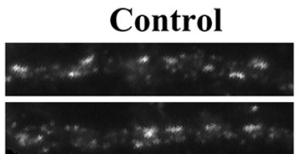

eNRG1
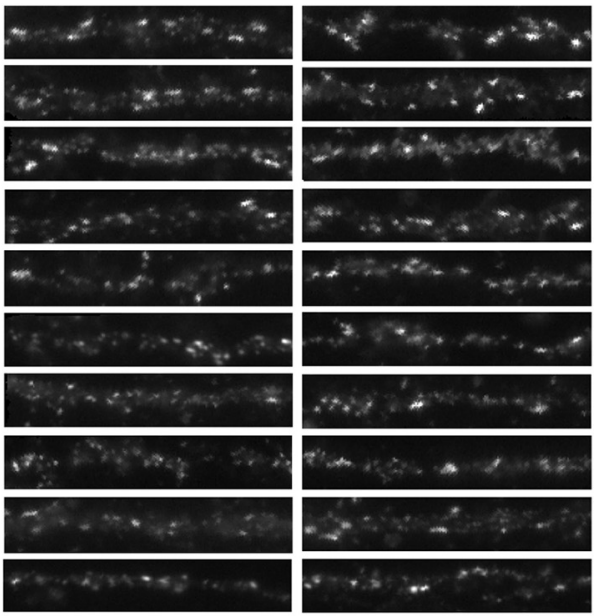

C

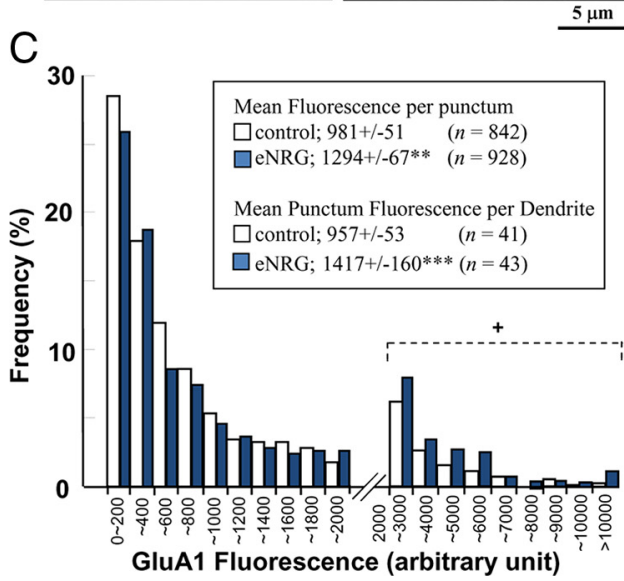

Figure 9. eNRG1 increases surface expression of GluA1 at punctate synaptic structures in cultured GABAergic neurons. Low-density neocortical cultures were prepared from rat embryos (E19) and grown for 2 weeks with or without eNRG1.A, Representative double labeling of surface GluA1 (white) and GAD67 (red) in untreated and eNRG1-treated GABAergic neurons is shown. Dendritic regions (20 $\mu \mathrm{m}$ in length, $20-40 \mu \mathrm{m}$ away from the soma) were selected randomly from GAD67-positive cells in three control sister cultures ( $n=41$ cells) and three eNRG1-treated sister cultures ( $n=43$ cells). $\boldsymbol{B}$, The top 10 pictures of dendrites showing the higher intensity GluA1 punctuate labeling were selected from each group and arranged from the top based on the signal intensity. $C$, The frequency of the puncta carrying the indicated range of surface GluA1 intensity was calculated and plotted $(n=842$ puncta on 41 dendrites in control cultures; $n=928$ puncta on 43 dendrites in eNRG1-treated cultures). ${ }^{* *} p<0.01,{ }^{* * *} p<0.001$, Student's $t$ test; ${ }^{+} p<0.01$, Wilcoxon's test.

ined synaptic activities and AMPA receptor expression in GABAergic interneurons in developing neocortex. We identified GABAergic neurons or the parvalbumin-positive subpopulation with immunostaining or their characteristic membrane excitabil- 
ity. Our results showed that postnatal eNRG1 treatment enhanced the magnitude of polysynaptically evoked IPSCs but not monosynaptically evoked IPSCs recorded from cortical pyramidal cells. Neighboring fast-spiking interneurons exhibited increased inward currents after local application of AMPA. The GABAergic subpopulation also showed increased mEPSC amplitudes, which was followed by increased mEPSC frequency with a time delay of $10 \mathrm{~d}$. The effects of eNRG1 on mEPSCs were reproduced by subchronic treatment with fNRG1, a full-length NRG1 type I. Higher levels of GluA1 protein, which is highly expressed in this cell population, were detected in the $\mathrm{PSD} /$ cytoskeletal fraction of eNRG1-treated neocortex. A significant increase in GluA1 immunoreactivity was observed at putative synaptic sites when cultured GABAergic neurons were grown in the presence of eNRG1. These findings reveal a novel activity for NRG1, which regulates AMPA receptor expression and function in postnatal GABAergic neurons.

In these experiments, we primarily used eNRG1, which consists of the core EGF domain of NRG1. This domain is shared by all NRG1 splice variants [types I-IV (Buonanno and Fischbach, 2001)], suggesting that it mediates biologic activities common to all forms of NRG1. Type I fNRG1 mimicked the effects of eNRG1, although the effects of fNRG1 on mEPSC frequency were more rapid and pronounced than those of eNRG1. The difference between results obtained with eNRG1 and ANRG1 may be a consequence of the heparin-binding domain of fNRG1, which is not present in eNRG1 (Li and Loeb, 2001).

\section{Acute and subchronic effects of NRG1 on excitatory input synapses in GABAergic neurons}

According to previous studies, NRG1 exerts different trophic effects on cortical GABAergic interneurons depending on the length of exposure to the neurotrophic factor (Woo et al., 2007; Barros et al., 2009; Fisahn et al., 2009; Fazzari et al., 2010). Acute effects include NRG1-triggered GABA release, which involves an increase in membrane excitability in presynaptic terminals (Woo et al., 2007; Wen et al., 2010). Thus, we do not rule out that a part of the present phenomena might have reflected the consequences of acute influences of eNRG1, although we failed to detect an effect on mEPSCs after acute application of eNRG1 to brain slices.

In a paired-pulse paradigm, eNRG1 did not markedly affect the presynaptic properties of GABAergic terminals. Correspondingly, eNRG1 had no effect on monosynaptic IPSCs and mIPSCs recorded from pyramidal neurons. Compared with synaptic outputs from GABAergic interneurons, synaptic inputs to these neurons were markedly affected by eNRG1. The eNRG1-induced increases in AMPA-evoked currents and mEPSCs both indicated that subchronic eNRG1 treatment enhanced AMPA receptor sensitivity of GABAergic neurons. This result was further supported by the biochemical and immunocytochemical evidence; there were significant increases in GluA1 levels in the PSD/cytoskeletal fraction and at putative synaptic sites in cultured GABAergic neurons.

In addition to elevated mEPSC amplitudes, eNRG1 and fNRG1 increased the $\mathrm{mEPSC}$ frequency in parvalbumin-positive GABAergic neurons, although the effect of eNRG1 on mEPSC frequency was delayed. These results suggest that NRG1 slowly promotes developmental maturation of and/or synapse formation at excitatory nerve terminals in this neuronal population. This explanation is in accordance with the reports that the activation of ErbB4 promotes presynaptic development of excitatory input synapses in hippocampal pyramidal cells ( $\mathrm{Li}$ et al., 2007;
Krivosheya et al., 2008) as well as in cultured cortical GABAergic neurons (Ting et al., 2011).

During the preparation and revision of this manuscript, the results of two studies describing knock-out mice lacking ErbB4 in this cell population have been published. Fazzari et al. (2010) found that long-term loss of ErbB4 diminishes the number of excitatory input synapses and inhibitory output synapses of these neurons. Ting et al. (2011) reported that the frequency and amplitude of mEPSCs are decreased in ErbB4-deficient GABAergic interneurons from adult mice. We have described a similar physiological activity of NRG1 on mEPSCs; not surprisingly, ErbB4deficient and NRG1-injected mice showed opposite effects. Therefore, results observed after peripheral NRG1 administration primarily reflect the direct effects of NRG1 on this cell population, although we cannot rule out that a part of the results may also be influenced by other factors responding to peripheral eNRG1 (Kato et al., 2011).

\section{Molecular mechanism of NRG1-triggerted increases in AMPA receptor levels}

In addition to ErbB4, cortical GABAergic interneurons express receptors for other neurotrophic factors, including BDNF, transforming growth factor $\alpha$, and EGF (Cellerino et al., 1996; Kornblum et al., 1997; Fox and Kornblum, 2005; Hashimoto et al., 2005). BDNF elevates the sensitivity of neurons to AMPA by stimulating cell surface translocation and stabilization of AMPA receptors (Narisawa-Saito et al., 1999, 2002; Jourdi et al., 2003; Nagano et al., 2003). This process involves enhanced interactions between AMPA receptors and scaffolding proteins, and $\mathrm{N}$-ethylmaleimide-sensitive factor-dependent vesicular exocytosis of the receptors (Narisawa-Saito et al., 2002; Jourdi et al., 2003). Although we were unable to extract intact molecular complexes of GluAl and postsynaptic scaffolding proteins, similarities in intracellular signaling from ErbB4 and TrkB receptor tyrosine kinases suggest that the receptor stabilization is presumably involved in the upregulation of AMPA receptor expression or function (Garcia et al., 2000; Li et al., 2007).

\section{Implications of peripheral NRG1 signals in developing GABAergic neurons}

Positively regulating incoming excitatory activity in GABAergic interneurons enhances inhibitory output signals and elevates synchronous neuronal coupling with the principal excitatory neurons in the neocortex (Cobb et al., 1995; Fuchs et al., 2007; Rácz et al., 2009). Conversely, attenuation of this incoming excitatory activity to these neurons causes behavioral phenotypes and pathophysiologic processes that resemble schizophrenia (Fuchs et al., 2007; Belforte et al., 2010). The present study suggests that enhanced NRG1 signals target synaptic AMPA receptors in the inhibitory interneurons and increase the strength of excitatory synaptic input to this particular cell type, resulting in enhanced GABA release. Therefore, our results indicate that NRG1 circulating in the periphery may have a crucial impact on the development of inhibitory function; it permeates the immature brain, acts on immature GABAergic neurons, promotes their inhibitory neurotransmission, and potentially influences cortical circuit organization (Hensch, 2005; Lewis et al., 2005; Fuchs et al., 2007).

NRG1 concentrations in human blood are as high as the dissociation constant for ErbB3 receptors and are reduced in patients with chronic schizophrenia (Shibuya et al., 2010). Thus, we hypothesize that downregulation of peripheral NRG1 expression may be associated with the deficits in GABAergic interneurons found in schizophrenia patients or various animal models of the 
disease (Lewis et al., 2005; Belforte et al., 2010; O’Donnell, 2010), although prenatal or perinatal NRG1 levels in subjects who later develop schizophrenia have not been documented. Our preliminary experiment suggests that the present eNRG1-treated animals later develop behavioral deficits such as reduced social interaction (T.K., unpublished data). Evaluation of peripheral NRG1 signals in human pathophysiologic or psychopathologic conditions associated with GABAergic neurons should be explored in future studies (Mei and Xiong, 2008).

\section{References}

Abe Y, Namba H, Zheng Y, Nawa H (2009) In situ hybridization reveals developmental regulation of ErbB1-4 mRNA expression in mouse midbrain: implication of ErbB receptors for dopaminergic neurons. Neuroscience 161:95-110.

Barros CS, Calabrese B, Chamero P, Roberts AJ, Korzus E, Lloyd K, Stowers L, Mayford M, Halpain S, Müller U (2009) Impaired maturation of dendritic spines without disorganization of cortical cell layers in mice lacking NRG1/ErbB signaling in the central nervous system. Proc Natl Acad Sci U S A 106:4507-4512.

Belforte JE, Zsiros V, Sklar ER, Jiang Z, Yu G, Li Y, Quinlan EM, Nakazawa K (2010) Postnatal NMDA receptor ablation in corticolimbic interneurons confers schizophrenia-like phenotypes. Nat Neurosci 13:76-83.

Buonanno A, Fischbach GD (2001) Neuregulin and ErbB receptor signaling pathways in the nervous system. Curr Opin Neurobiol 11:287-296.

Burden S, Yarden Y (1997) Neuregulins and their receptors: a versatile signaling module in organogenesis and oncogenesis. Neuron 18:847-855.

Cellerino A, Maffei L, Domenici L (1996) The distribution of brain-derived neurotrophic factor and its receptor trkB in parvalbumin-containing neurons of the rat visual cortex. Eur J Neurosci 8:1190-1197.

Cobb SR, Buhl EH, Halasy K, Paulsen O, Somogyi P (1995) Synchronization of neuronal activity in hippocampus by individual GABAergic interneurons. Nature 378:75-78.

Dumitriu D, Cossart R, Huang J, Yuste R (2007) Correlation between axonal morphologies and synaptic input kinetics of interneurons from mouse visual cortex. Cereb Cortex 17:81-91.

Falls DL (2003) Neuregulins: functions, forms, and signaling strategies. Exp Cell Res 284:14-30.

Fazzari P, Paternain AV, Valiente M, Pla R, Luján R, Lloyd K, Lerma J, Marín O, Rico B (2010) Control of cortical GABA circuitry development by Nrg1 and ErbB4 signalling. Nature 464:1376-1380.

Fisahn A, Neddens J, Yan L, Buonanno A (2009) Neuregulin-1 modulates hippocampal gamma oscillations: implications for schizophrenia. Cereb Cortex 19:612-618.

Flames N, Long JE, Garratt AN, Fischer TM, Gassmann M, Birchmeier C, Lai C, Rubenstein JL, Marín O (2004) Short- and long-range attraction of cortical GABAergic interneurons by neuregulin-1. Neuron 44:251-261.

Fleidervish IA, Gutnick MJ (1995) Paired-pulse facilitation of IPSCs in slices of immature and mature mouse somatosensory neocortex. J Neurophysiol 73:2591-2595.

Fox IJ, Kornblum HI (2005) Developmental profile of ErbB receptors in murine central nervous system: implications for functional interactions. J Neurosci Res 79:584-597.

Fuchs EC, Zivkovic AR, Cunningham MO, Middleton S, Lebeau FE, Bannerman DM, Rozov A, Whittington MA, Traub RD, Rawlins JN, Monyer H (2007) Recruitment of parvalbumin-positive interneurons determines hippocampal function and associated behavior. Neuron 53:591-604.

Garcia RA, Vasudevan K, Buonanno A (2000) The neuregulin receptor ErbB-4 interacts with PDZ-containing proteins at neuronal synapses. Proc Natl Acad Sci U S A 97:3596-3601.

Gerecke KM, Wyss JM, Karavanova I, Buonanno A, Carroll SL (2001) ErbB transmembrane tyrosine kinase receptors are differentially expressed throughout the adult rat central nervous system. J Comp Neurol 433: 86-100.

Gu Z, Jiang Q, Fu AK, Ip NY, Yan Z (2005) Regulation of NMDA receptors by neuregulin signaling in prefrontal cortex. J Neurosci 25:4974-4984.

Hashimoto T, Bergen SE, Nguyen QL, Xu B, Monteggia LM, Pierri JN, Sun Z, Sampson AR, Lewis DA (2005) Relationship of brain-derived neurotrophic factor and its receptor TrkB to altered inhibitory prefrontal circuitry in schizophrenia. J Neurosci 25:372-383.
Hensch TK (2005) Critical period plasticity in local cortical circuits. Nat Rev Neurosci 6:877-888.

Itami C, Kimura F, Nakamura S (2007) Brain-derived neurotrophic factor regulates the maturation of layer 4 fast-spiking cells after the second postnatal week in the developing barrel cortex. J Neurosci 27:2241-2252.

Iwakura Y, Piao YS, Mizuno M, Takei N, Kakita A, Takahashi H, Nawa H (2005) Influences of dopaminergic lesion on epidermal growth factorErbB signals in Parkinson's disease and its model: neurotrophic implication in nigrostriatal neurons. J Neurochem 93:974-983.

Jourdi H, Iwakura Y, Narisawa-Saito M, Ibaraki K, Xiong H, Watanabe M, Hayashi Y, Takei N, Nawa H (2003) Brain-derived neurotrophic factor signal enhances and maintains the expression of AMPA receptorassociated PDZ proteins in developing cortical neurons. Dev Biol 263:216-230.

Kato T, Abe Y, Sotoyama H, Kakita A, Kominami R, Hirokawa S, Ozaki M, Takahashi H, Nawa H (2011) Transient exposure of neonatal mice to neuregulin-1 results in hyperdopaminergic states in adulthood: implication in neurodevelopmental hypothesis for schizophrenia. Mol Psychiatry $16: 307-320$

Kawaguchi Y, Kondo S (2002) Parvalbumin, somatostatin and cholecystokinin as chemical markers for specific GABAergic interneuron types in the rat frontal cortex. J Neurocytol 31:277-287.

Kawaguchi Y, Kubota Y (1997) GABAergic cell subtypes and their synaptic connections in rat frontal cortex. Cereb Cortex 7:476-486.

Kharazia VN, Wenthold RJ, Weinberg RJ (1996) GluR1-immunopositive interneurons in rat neocortex. J Comp Neurol 368:399-412.

Kim TJ, Ye EA, Jeon CJ (2006) Distribution of AMPA glutamate receptor GluR1 subunit-immunoreactive neurons and their co-localization with calcium-binding proteins and GABA in the mouse visual cortex. Mol Cells 21:34-41.

Kleshcheva RP (1988) The development of components of the blood-brain barrier in the neocortex of the white rat. Arkh Anat Gistol Embriol 95:22-26.

Kondo M, Okabe S, Sumino R, Okado H (2000) A high GluR1: GluR2 expression ratio is correlated with expression of $\mathrm{Ca}^{2+}$-binding proteins in rat forebrain neurons. Eur J Neurosci 12:2812-2822.

Kornblum HI, Hussain RJ, Bronstein JM, Gall CM, Lee DC, Seroogy KB (1997) Prenatal ontogeny of the epidermal growth factor receptor and its ligand, transforming growth factor alpha, in the rat brain. J Comp Neurol 380:243-261.

Krivosheya D, Tapia L, Levinson JN, Huang K, Kang Y, Hines R, Ting AK, Craig AM, Mei L, Bamji SX, El-Husseini A (2008) ErbB4-neuregulin signaling modulates synapse development and dendritic arborization through distinct mechanisms. J Biol Chem 283:32944-32956.

Kwon OB, Paredes D, Gonzalez CM, Neddens J, Hernandez L, Vullhorst D, Buonanno A (2008) Neuregulin-1 regulates LTP at CA1 hippocampal synapses through activation of dopamine D4 receptors. Proc Natl Acad Sci U S A 105:15587-15592.

Lambert NA, Wilson WA (1994) Temporally distinct mechanisms of usedependent depression at inhibitory synapses in the rat hippocampus in vitro. J Neurophysiol 72:121-130.

Lewis DA, Hashimoto T, Volk DW (2005) Cortical inhibitory neurons and schizophrenia. Nat Rev Neurosci 6:312-324.

Li B, Woo RS, Mei L, Malinow R (2007) The neuregulin-1 receptor erbB4 controls glutamatergic synapse maturation and plasticity. Neuron 54:583-597.

Li Q, Loeb JA (2001) Neuregulin-heparan-sulfate proteoglycan interactions produce sustained erbB receptor activation required for the induction of acetylcholine receptors in muscle. J Biol Chem 276:38068-38075.

Ling DS, Benardo LS (1995) Recruitment of GABAA inhibition in rat neocortex is limited and not NMDA dependent. J Neurophysiol 74:2329-2335.

McNeill RB, Colbran RJ (1995) Interaction of autophosphorylated $\mathrm{Ca}^{2+} /$ calmodulin-dependent protein kinase II with neuronal cytoskeletal proteins. Characterization of binding to a $190-\mathrm{kDa}$ postsynaptic density protein. J Biol Chem 270:10043-10049.

Mei L, Xiong WC (2008) Neuregulin 1 in neural development, synaptic plasticity and schizophrenia. Nat Rev Neurosci 9:437-452.

Milstein AD, Nicoll RA (2008) Regulation of AMPA receptor gating and pharmacology by TARP auxiliary subunits. Trends Pharmacol Sci 29: 333-339.

Nagano T, Yanagawa Y, Obata K, Narisawa-Saito M, Namba H, Otsu Y, Takei N, Nawa H (2003) Brain-derived neurotrophic factor upregulates and 
maintains AMPA receptor currents in neocortical GABAergic neurons. Mol Cell Neurosci 24:340-356.

Nagano T, Namba H, Abe Y, Aoki H, Takei N, Nawa H (2007) In vivo administration of epidermal growth factor and its homologue attenuates developmental maturation of functional excitatory synapses in cortical GABAergic neurons. Eur J Neurosci 25:380-390.

Namba H, Nagano T, Iwakura Y, Xiong H, Jourdi H, Takei N, Nawa H (2006) Transforming growth factor alpha attenuates the functional expression of AMPA receptors in cortical GABAergic neurons. Mol Cell Neurosci 31:628-641.

Narisawa-Saito M, Carnahan J, Araki K, Yamaguchi T, Nawa H (1999) Brain-derived neurotrophic factor regulates the expression of AMPA receptor proteins in neocortical neurons. Neuroscience 88:1009-1014.

Narisawa-Saito M, Iwakura Y, Kawamura M, Araki K, Kozaki S, Takei N, Nawa H (2002) Brain-derived neurotrophic factor regulates surface expression of alpha-amino-3-hydroxy-5-methyl-4-isoxazoleproprionic acid receptors by enhancing the N-ethylmaleimide-sensitive factor/ GluR2 interaction in developing neocortical neurons. J Biol Chem 277:40901-40910.

Nawa H, Takei N (2001) BDNF as an anterophin; a novel neurotrophic relationship between brain neurons. Trends Neurosci 24:683-684; discussion 684-685.

O’Donnell P (2010) Adolescent maturation of cortical dopamine. Neurotox Res 18:306-312.

Okada M, Corfas G (2004) Neuregulin1 downregulates postsynaptic GABAA receptors at the hippocampal inhibitory synapse. Hippocampus 14:337-344.

Ozaki M, Sasner M, Yano R, Lu HS, Buonanno A (1997) Neuregulin-beta induces expression of an NMDA-receptor subunit. Nature 390:691-694.

Ozaki M, Itoh K, Miyakawa Y, Kishida H, Hashikawa T (2004) Protein processing and releases of neuregulin-1 are regulated in an activitydependent manner. J Neurochem 91:176-188.

Puig MV, Ushimaru M, Kawaguchi Y (2008) Two distinct activity patterns of fast-spiking interneurons during neocortical UP states. Proc Natl Acad Sci U S A 105:8428-8433.

Rácz A, Ponomarenko AA, Fuchs EC, Monyer H (2009) Augmented hippocampal ripple oscillations in mice with reduced fast excitation onto parvalbumin-positive cells. J Neurosci 29:2563-2568.

Sasaki S, Huda K, Inoue T, Miyata M, Imoto K (2006) Impaired feedforward inhibition of the thalamocortical projection in epileptic $\mathrm{Ca}^{2+}$ channel mutant mice, tottering. J Neurosci 26:3056-3065.

Shibuya M, Komi E, Wang R, Kato T, Watanabe Y, Sakai M, Ozaki M, Someya T, Nawa H. (2010) Measurement and comparison of serum neuregulin 1 immunoreactivity in control subjects and patients with schizophrenia: an influence of its genetic polymorphism. J Neural Transm 117:887-895.
Stefansson H, Sigurdsson E, Steinthorsdottir V, Bjornsdottir S, Sigmundsson T, Ghosh S, Brynjolfsson J, Gunnarsdottir S, Ivarsson O, Chou TT, Hjaltason O, Birgisdottir B, Jonsson H, Gudnadottir VG, Gudmundsdottir E, Bjornsson A, Ingvarsson B, Ingason A, Sigfusson S, Hardardottir H, et al. (2002) Neuregulin 1 and susceptibility to schizophrenia. Am J Hum Genet 71:877-892.

Steiner H, Blum M, Kitai ST, Fedi P (1999) Differential expression of ErbB3 and ErbB4 neuregulin receptors in dopamine neurons and forebrain areas of the adult rat. Exp Neurol 159:494-503.

Swayze RD, Lisé MF, Levinson JN, Phillips A, El-Husseini A (2004) Modulation of dopamine mediated phosphorylation of AMPA receptors by PSD-95 and AKAP79/150. Neuropharmacology 47:764-778.

Ting AK, Chen Y, Wen L, Yin DM, Shen C, Tao Y, Liu X, Xiong WC, Mei L (2011) Neuregulin 1 promotes excitatory synapse development and function in GABAergic interneurons. J Neurosci 31:15-25.

Tohmi M, Tsuda N, Zheng Y, Mizuno M, Sotoyama H, Shibuya M, Kawamura M, Kakita A, Takahashi H, Nawa H (2007) The cellular and behavioral consequences of interleukin- 1 alpha penetration through the blood-brain barrier of neonatal rats: a critical period for efficacy. Neuroscience 150:234-250.

Vullhorst D, Neddens J, Karavanova I, Tricoire L, Petralia RS, McBain CJ, Buonanno A (2009) Selective expression of ErbB4 in interneurons, but not pyramidal cells, of the rodent hippocampus. J Neurosci 29:12255-12264.

Wen L, Lu YS, Zhu XH, Li XM, Woo RS, Chen YJ, Yin DM, Lai C, Terry AV Jr, Vazdarjanova A, Xiong WC, Mei L (2010) Neuregulin 1 regulates pyramidal neuron activity via ErbB4 in parvalbumin-positive interneurons. Proc Natl Acad Sci U S A 107:1211-1216.

Woo RS, Li XM, Tao Y, Carpenter-Hyland E, Huang YZ, Weber J, Neiswender H, Dong XP, Wu J, Gassmann M, Lai C, Xiong WC, Gao TM, Mei L (2007) Neuregulin-1 enhances depolarization-induced GABA release. Neuron 54:599-610.

Xie F, Raetzman LT, Siegel RE (2004) Neuregulin induces GABAA receptor beta2 subunit expression in cultured rat cerebellar granule neurons by activating multiple signaling pathways. J Neurochem 90:1521-1529.

Yau HJ, Wang HF, Lai C, Liu FC (2003) Neural development of the neuregulin receptor ErbB4 in the cerebral cortex and the hippocampus: preferential expression by interneurons tangentially migrating from the ganglionic eminences. Cereb Cortex 13:252-264.

Zhong C, Du C, Hancock M, Mertz M, Talmage DA, Role LW (2008) Presynaptic type III neuregulin 1 is required for sustained enhancement of hippocampal transmission by nicotine and for axonal targeting of $\alpha 7$ nicotinic acetylcholine receptors. J Neurosci 28:9111-9116. 